\title{
Valorisation of table tomato crop by-products: Phenolic profiles and in vitro antioxidant and antimicrobial activities
}

\author{
Mikel Añibarro-Ortega ${ }^{a, 1}$, José Pinela ${ }^{a, *, 1}$, Ana Ćirić ${ }^{b}$, Valter Martins ${ }^{c}$, \\ Filomena Rocha ${ }^{c}$, Marina D. Soković ${ }^{b}$, Ana Maria Barata ${ }^{c}$, \\ Ana Maria Carvalho ${ }^{a}$, Lillian Barros ${ }^{a, *}$, Isabel C.F.R. Ferreira ${ }^{a}$ \\ a Centro de Investigação de Montanha (CIMO), Instituto Politécnico de Bragança, Campus de Santa Apolónia, \\ 5300-253 Bragança, Portugal \\ b Institute for Biological Research "Siniša Stankovič" - National Institute of Republic of Serbia, University of \\ Belgrade, Bulevar Despota Stefana 142, 11000 Belgrade, Serbia \\ c Banco Português de Germoplasma Vegetal (BPGV), Instituto Nacional de Investigação Agrária e Veterinária, I.P. \\ (INIAV, I.P.), IP, Quinta S. José, S. Pedro de Merelim, 4700-859 Braga, Portugal
}

\section{A R T I C L E I N F O}

\section{Article history:}

Received 26 April 2020

Received in revised form 3

September 2020

Accepted 4 September 2020

Available online 19 September 2020

Keywords:

Table tomato varieties

By-products valorization

Phenolic compounds

Antioxidant activity

Antimicrobial activity

Chlorophylls

\begin{abstract}
A B S T R A C T
Little attention has been paid to the phenolic composition and bioactive properties of primary tomato plant by-products (Solanum lycopersicum L.) as compared to fruits. In this study, axillary green shoots resulting from pruning and aerial biomass at the end of the cultivation cycle were characterized for their composition in chlorophylls and phenolic compounds, as well as for antioxidant and antimicrobial activities. The HPLC-DAD-ESI/MS ${ }^{n}$ analysis allowed identifying phenolic acids and flavonoids, with prevalence of quercetin3-O-rutinoside (rutin). The extracts had in vitro antioxidant and antihemolytic activity, especially those produced from pruning materials. Despite their low activity against the tested microfungi, some extracts had ability to inhibit and kill some bacteria more effectively than the antibiotic ampicillin. It was interesting to conclude that table tomato crop remains, currently with no commercial value, can be used to produce extracts with antioxidant and antibacterial activities for possible use in the agri-food sector as natural preservatives.

(c) 2020 Institution of Chemical Engineers. Published by Elsevier B.V. All rights reserved.
\end{abstract}

\section{Introduction}

Tomato (Solanum lycopersicum L. syn. Lycopersicon esculentum Mill., Fam. Solanaceae) is the world's largest vegetable crop after potato and sweet potato and an important component of the human diet. In 2018, the global area under tomato was 4762 thousand ha and the production was around 182 million tonnes, for both fresh and processed consumption (FAOSTAT, 2019). Considering the production of table tomatoes for fresh consumption in the EU-28, Spain was the main producer in 2019 (30\%) and Portugal was in the eleventh position (European Commission, 2019). Nevertheless, in Portugal, fresh tomato was the horticultural crop with the highest production (104 thousand tons) in 2019 (INE, 2019). Tomato production generates annually a considerable amount of plant by-products with no commercial value, linked manly to the pruning and harvest remains. Therefore, given the current and future needs of the human population and the finite resources our planet can pro-

\footnotetext{
* Corresponding authors.

E-mail addresses: jpinela@ipb.pt (J. Pinela), lillian@ipb.pt (L. Barros).

1 The authors contributed equally.

https://doi.org/10.1016/j.fbp.2020.09.006

0960-3085/๑ 2020 Institution of Chemical Engineers. Published by Elsevier B.V. All rights reserved.
} 
vide, it is necessary to move from the current unsustainable production system to a circular and more resource-efficient paradigm (Independent Group of Scientists appointed by the Secretary-General, 2019). In this regard, table tomato crop by-products can be recovered and recycled into bio-based ingredients with bioactive properties for application in different industrial sectors.

Table tomato varieties are sown and growth every year, resulting in an annual scaling production of fruits and remaining a substantial amount of aerial parts consisting on stems, branches, and leaves. The fruit is consumed fresh, while the rest of the plant is always discarded as recyclable waste. Tomato crops can grow continually throughout the year, under environmentally controlled conditions, and require regular cropping practices, such as pruning, sanitation, and irrigation, among others (Gould, 1992). Specifically pruning consists of removing unwanted shoots and leaves and is carried out to prevent the development of a broad branching growth habit that restricts the fruit size and quality and promotes foliage diseases (Kim et al., 2014; Teitel et al., 2016). Farmers usually burn and use as compost the aerial parts remaining from pruning. However, the disposal of crop remains may represent a risk of introduction or spread of some plant pathogens (Noble et al., 2009). On the other hand, there is an increasing demand for conversion of plant by-products into high value-added products (Galanakis, 2013). This approach aims to avoid the environmental impact of these bio-residues and to recover bioactive molecules through a strategy focused on "zero waste" and a circular economy.

Nowadays, the emergence of novel methods for extraction and purification of biomolecules have caused great interest in agricultural (tomato, potato, olive, cereals, berries, etc.) by-products valorisation as sustainable sources of functional ingredients (Fritsch et al., 2017; Galanakis, 2019, 2013, 2012). Examples include the use of ultrasounds, microwaves, electrical technologies, and high pressures to improve the extraction of proteins, fibres, phenolic compounds, and glucosinolates, among other high-added value compounds (Barba et al., 2015; Deng et al., 2015; Galanakis, 2013), and ultrafiltration to separate different size molecules (Galanakis, 2015). These studies normally follow the so-called " 5 -stages universal recovery process" that includes all stages from the macroscopic pre-treatment of the plant material to the final product formulation (Barba et al., 2015; Deng et al., 2015; Galanakis, 2012). The obtained products have received different applications, such as food additives/supplements (Galanakis, 2018) and functional ingredients for cosmetics and sunscreens (Galanakis et al., 2018). In addition, in this new era of pandemic crises, it is important to promote the development of more sustainable agri-food systems due to their directly impact on human health (Galanakis, 2020).

The tomato fruit is a well-documented source of dietary antioxidants such as carotenoids, vitamins, and phenolic compounds (Pinela et al., 2012, 2016, 2019), but little information is available in the literature concerning the non-edible green tissues of this plant. Some authors have already evaluate bioactive properties and chemical aspects of tomato leaves (Figueiredo-González et al., 2017, 2016; Silva-Beltrán et al., 2015; Taveira et al., 2012), highlighting these by-products as promising sources of bioactive constituents, including phenolics, carotenoids, and alkaloids, for the management of Alzheimer's disease and diabetes mellitus, as well as the cytotoxic effects of alkaloid-rich extracts for gastric cancer cells. These findings suggested the exploitation of tomato by- products bioactives in the nutraceutical and pharmaceutical industries. Its potential for the production of green pellets, levulinic acid, and food microorganisms, and the extraction of volatile aroma components have also been proposed (Fritsch et al., 2017).

The present study was performed to characterize the phenolic profile and the antioxidant and antimicrobial properties of tomato crop remains (pruning and end-of-cycle plant materials), resulting from the regeneration of Portuguese tomato landraces conserved ex-situ in the Portuguese Genebank (BPGV), in order to identify novel applications and promote their recycling within the agri-food sector.

\section{Material and methods}

\subsection{Plant material and samples preparation}

The plant material for analysis resulted from the regeneration (replenishing seed stocks, following international guidelines for genebanks) of table tomato accessions conserved ex-situ in the Portuguese Genebank (BPGV). The seeds of the selected accessions were cultivated in BPGV experimental fields in Braga, Portugal. All the procedures followed the International Genebank Standards for tomato species and varieties (FAO, 2014; UPOV, 2013). Moreover, the trials were installed under the same soil and climatic conditions and agronomic management (e.g., plantation, irrigation, pruning, phytosanitary treatments, and harvesting techniques); the plants (populations) corresponding to each accession were grown under spatial isolation by artificial barriers. Therefore, it is expected that this approach has reduced abiotic effects on the chemical composition of the analysed plant material (Pinela et al., 2019). Such plant materials consisted of: (i) axillary green shoots (or suckers) from pruning performed after the flowering period to create an optimal balance of vegetative growth and fruit production; and (ii) aerial biomass at the end of the cultivation cycle. The accession code, local name, fruit type, and geographic origin of the regenerated tomato accessions are described in Table 1. Considering the purposes of this study, the same table also summarizes the most interesting morphological characteristics of tomato plants from each accession. The fresh weight of each sample of the gathered plant material was measured; such samples were freeze-dried (FreeZone 4.5 model 7750031, Labconco, Kansas City, USA), reduced to powder ( $\sim 20 \mathrm{mesh})$ and kept at $-20^{\circ} \mathrm{C}$ until analysis.

\subsection{Determination of chlorophyll content}

The powdered samples ( $500 \mathrm{mg}$ ) were mixed with $10 \mathrm{~mL}$ of acetone-hexane $(4: 6, v / v)$, shaken vigorously for $1 \mathrm{~min}$ and a portion was quickly filtered through Whatman No 4 filter paper by gravity to measure the absorbance (A) at 645 and 663 $\mathrm{nm}$ in a spectrophotometer (AnalytikJena 200, Jena, Germany) (Nagata and Yamashita, 1992). The chlorophyll $a$ and $b$ contents were estimated using Eqs. (1) and (2), respectively, and expressed as mg per $100 \mathrm{~g}$ of fresh weight (fw).

Chlorophylla $=0.999 \times A_{663}-0.0989 \times A_{645}$

Chlorophyllb $=-0.328 \times \mathrm{A}_{663}+1.77 \times \mathrm{A}_{645}$ 
Table 1 - Main features and morphological characteristics of each tomato accessions. Most interesting descriptors at the flowering and harvest season, according the descriptors for tomato (Lycopersicon spp.) provided by the International Plant Genetic Resources Institute Secretariat (IBPGR, 1996).

\begin{tabular}{|c|c|c|c|c|c|c|}
\hline & BPGV 12260 & BPGV 12437 & BPGV 12446 & BPGV $12465^{*}$ & BPGV 12906 & BPGV 13034 \\
\hline \multicolumn{7}{|c|}{ Tomato accessions main features } \\
\hline $\begin{array}{l}\text { PT local name (literal } \\
\text { meaning in EN) }\end{array}$ & $\begin{array}{l}\text { Tomate } \\
\text { coração-de-boi } \\
\text { (oxheart tomato) }\end{array}$ & $\begin{array}{l}\text { Tomate amarelo } \\
\text { (yellow tomato) }\end{array}$ & $\begin{array}{l}\text { Tomate antigo } \\
\text { (old tomato) }\end{array}$ & $\begin{array}{l}\text { Tomate sem } \\
\text { varas (no staking } \\
\text { tomato) }\end{array}$ & Tomate (tomato) & $\begin{array}{l}\text { Tomate } \\
\text { coração-de-boi } \\
\text { (oxheart tomato) }\end{array}$ \\
\hline Similar commercial type & Beefsteak tomato & Yellow tomato & Beefsteak tomato & Round standard & $\begin{array}{l}\text { Elongated } \\
\text { tomato }\end{array}$ & Beefsteak tomato \\
\hline \multicolumn{7}{|l|}{ Geographic origin } \\
\hline Region & Bragança & Bragança & Bragança & Bragança & Aveiro & Guarda \\
\hline Collecting site & $\begin{array}{l}\text { Santulhão, } \\
\text { Vimioso }\end{array}$ & $\begin{array}{l}\text { Águas Vivas, } \\
\text { Miranda do } \\
\text { Douro }\end{array}$ & $\begin{array}{l}\text { Águas Vivas, } \\
\text { Miranda do } \\
\text { Douro }\end{array}$ & $\begin{array}{l}\text { Peredo da } \\
\text { Bemposta, } \\
\text { Mogadouro }\end{array}$ & $\begin{array}{l}\text { Frossos, } \\
\text { Albergaria-a- } \\
\text { Velha }\end{array}$ & Teixeira, Seia \\
\hline \multicolumn{7}{|c|}{ Morphological characteristics ${ }^{\#}$} \\
\hline Growth habit & Determinated & Determinated & Determinated & Determinated & Indeterminate & Indeterminate \\
\hline $\begin{array}{l}\text { Plant width at flowering } \\
\text { season }(\mathrm{cm})\end{array}$ & $65 \pm 10^{a, b}$ & $72 \pm 8^{a, b}$ & $90 \pm 15^{a}$ & $55 \pm 3^{b}$ & $76 \pm 16^{\mathrm{a}, \mathrm{b}}$ & $75 \pm 15^{a, b}$ \\
\hline $\begin{array}{l}\text { Plant height at flowering } \\
\text { season }(\mathrm{cm})\end{array}$ & $52 \pm 12$ & $64 \pm 14$ & $74 \pm 6$ & $47 \pm 5$ & $68 \pm 8$ & $67 \pm 14$ \\
\hline $\begin{array}{l}\text { Plant width at maturation } \\
\text { season }(\mathrm{cm})\end{array}$ & $78 \pm 10^{a, b}$ & $85 \pm 6^{a}$ & $80 \pm 7^{a, b}$ & $54 \pm 6^{b}$ & $85 \pm 9^{a}$ & $82 \pm 15^{a}$ \\
\hline $\begin{array}{l}\text { Plant height at maturation } \\
\text { season }(\mathrm{cm})\end{array}$ & $91 \pm 10^{b}$ & $116 \pm 31^{b, c}$ & $183 \pm 25^{a}$ & $72 \pm 8^{b}$ & $173 \pm 17^{a}$ & $163 \pm 14^{a, b}$ \\
\hline Leaf length $(\mathrm{cm})$ & $11.1 \pm 0.9^{\mathrm{a}, \mathrm{b}}$ & $13 \pm 1^{\mathrm{a}, \mathrm{b}}$ & $14 \pm 1^{\mathrm{a}}$ & $9 \pm 3^{b}$ & $13 \pm 2^{\mathrm{a}, \mathrm{b}}$ & $11 \pm 1^{\mathrm{a}, \mathrm{b}}$ \\
\hline Leaf width (cm) & $5.6 \pm 0.4^{\mathrm{a}, \mathrm{b}, \mathrm{c}}$ & $5.9 \pm 0.5^{\mathrm{a}, \mathrm{b}}$ & $6.3 \pm 0.4^{a}$ & $4.7 \pm 0.9^{b, c}$ & $5.1 \pm 0.6^{a, b, c}$ & $4.2 \pm 0.2^{c}$ \\
\hline
\end{tabular}

* The accession did not produce enough axillary shoots or suckers to be pruned.

\# Observations made on 12 plants of each accession; measurements of 10 leaves from each plant. The results are presented as mean \pm standard deviation. In each line, different letters correspond to significant differences $(p<0.05)$ between accessions.

\subsection{Preparation of plant extracts}

Hydroethanolic extracts were prepared according to a method formerly described (Pinela et al., 2012), but with some modifications. Briefly, approximately $1 \mathrm{~g}$ of the powdered samples was stirred with $30 \mathrm{~mL}$ of $80 \%$ ethanol for $1 \mathrm{~h}$. The supernatant was filtered through Whatman No. 4 filter paper and the residue was re-extracted under the same conditions. The filtrates were concentrated in a rotary evaporator (Büchi R-210, Flawil, Switzerland) with a bath temperature of $40^{\circ} \mathrm{C}$ and the aqueous phase was freeze-dried. The extract weight resulting from each extraction was evaluated to determine the extraction yield (\%, g extract/g sample). The lyophilized extracts were kept under vacuum at $-20{ }^{\circ} \mathrm{C}$ until analysis.

\subsection{Evaluation of bioactive properties}

\subsubsection{Total phenolics and flavonoids}

The total phenolic content was determined by the FolinCiocalteu method described by Reis et al. (2011). Briefly, $1 \mathrm{~mL}$ of the extract solutions $(2.5 \mathrm{mg} / \mathrm{mL}$ in $80 \%$ ethanol) was mixed with $5 \mathrm{~mL}$ of Folin-Ciocalteu solution $(1: 10, \mathrm{v} / \mathrm{v})$ and $4 \mathrm{~mL}$ of sodium carbonate $(75 \mathrm{~g} / \mathrm{L})$. The tubes were vortex mixed and allowed to stand for $30 \mathrm{~min}$ at $40{ }^{\circ} \mathrm{C}$. The absorbance was measured at $765 \mathrm{~nm}$ in the spectrophotometer referred above. Gallic acid [0.05-0.8 $\mathrm{mg} / \mathrm{mL}$ ] was used to obtain the calibration curve $\left(\mathrm{y}=2.0372 \mathrm{x}+0.043 ; \mathrm{R}^{2}=0.9981\right)$ and the results were expressed as $\mathrm{mg}$ of gallic acid equivalents (GAEs) per $\mathrm{g}$ of extract.

The total flavonoid content was determined in extract solutions at $5 \mathrm{mg} / \mathrm{mL}$ (using $80 \%$ ethanol to prepare them) by the aluminium chloride colorimetric method with slight modifications (Barros et al., 2010). The flavonoid-aluminium complexes formed in the system were monitored at $510 \mathrm{~nm}$. Catechin [0.03125-1 mg/mL] was used to obtain the calibration curve (y $\left.=0.8578 \mathrm{x}+2 \mathrm{E}^{-05} ; \mathrm{R}^{2}=0.9999\right)$ and the results were expressed as $\mathrm{mg}$ of catechin equivalents (CE) per $\mathrm{g}$ of extract.

\subsubsection{Antioxidant activity}

2.4.2.1. Radical-scavenging activity (RSA). Thirty microliters of the extract solutions $(0.15-5 \mathrm{mg} / \mathrm{mL}$ in $80 \%$ ethanol) were mixed with $270 \mu \mathrm{L}$ of DPPH methanolic solution $\left(6 \times 10^{-5} \mathrm{M}\right)$ in a 96-well plate. After 30-min incubation in the dark, the absorbance was measured at $515 \mathrm{~nm}$ in a plate reader (BioTek Instruments, ELX800) (Pinela et al., 2012). Trolox (3.125-100 $\mu \mathrm{g} / \mathrm{mL}$ ) was used as a positive control. The RSA was calculated using Eq. (3), where $A_{S}$ and $A_{D P P H}$ correspond to the absorbances of the extract mixture and control, respectively, and were expressed as $\mathrm{EC}_{50}$ values $(\mathrm{mg} / \mathrm{mL})$.

$\operatorname{RSA}(\%)=\left(\frac{A_{D P P H}-A_{S}}{A_{D P P H}}\right) \times 100$

2.4.2.2. Reducing power. Five hundred microliters of the extract solutions $(0.15-5 \mathrm{mg} / \mathrm{mL}$ in $80 \%$ ethanol) were mixed with $0.5 \mathrm{~mL}$ of sodium phosphate buffer $(200 \mathrm{mM}$, pH 6.6) and $0.5 \mathrm{~mL}$ of potassium ferricyanide $(1 \% \mathrm{w} / \mathrm{v})$. After incubation at $50{ }^{\circ} \mathrm{C}$ for $20 \mathrm{~min}, 0.5 \mathrm{~mL}$ of trichloroacetic acid $(10 \% \mathrm{w} / \mathrm{v})$ were added and $0.8-\mathrm{mL}$ aliquots of this mixture were transferred to a 48 -well plate containing $0.8 \mathrm{~mL}$ of deionised water and $0.16 \mathrm{~mL}$ of ferric chloride $(0.1 \% \mathrm{w} / \mathrm{v})$. The absorbance was measured at $690 \mathrm{~nm}$ in the plate reader referred above (Pinela et al., 2012). Trolox (3.125-100 $\mu \mathrm{g} / \mathrm{mL}$ ) was used as a positive control. The results were given as $\mathrm{EC}_{50}$ values $(\mathrm{mg} / \mathrm{mL})$.

2.4.2.3. Antihemolytic activity. Two hundred microliters of sheep erythrocyte solution $(2.8 \%$ in PBS, $v / v)$ were mixed with 
$400 \mu \mathrm{L}$ of either extract solution (0.31-2.5 $\mu \mathrm{g} / \mathrm{mL}$ in PBS), PBS solution (control), or water (for complete haemolysis) in a flat bottom 48-well plate. Trolox (3.91-125 $\mu \mathrm{g} / \mathrm{mL}$ ) was used as a positive control. After pre-incubation at $37^{\circ} \mathrm{C}$ for $10 \mathrm{~min}$ with shaking, $200 \mu \mathrm{L}$ of 2.2'-azobis(2-methylpropionamidine) dihydrochloride (AAPH, $160 \mathrm{mM}$ in PBS) were added and the optical density was measured at $690 \mathrm{~nm}$ in the plate reader referred above. After that, the microplate was incubated under the same conditions and the optical density was measured every $\sim 10$ min at the same wavelength until complete haemolysis. Data were processed as described by Lockowandt et al. (2019) and the results were expressed as $I_{50}$ values $(\mu \mathrm{g} / \mathrm{mL})$ for a $\Delta t$ of $60 \mathrm{~min}$.

\subsubsection{Antimicrobial activity}

The extracts were dissolved in 5\% DMSO and screened against Bacillus cereus (clinical isolate), Staphylococcus aureus (ATCC 6538), Listeria monocytogenes (NCTC 7973), Escherichia coli (ATCC 35210), Enterobacter cloacae (ATCC 35030), and Salmonella typhimurium (ATCC 13311). Aspergillus fumigatus (ATCC 1022), Aspergillus ochraceus (ATCC 12066), Aspergillus niger (ATCC 6275), Penicillium ochrochloron (ATCC 9112), Penicillium funiculosum (ATCC 36839), and Penicillium verrucosum var. cyclopium (food isolate) were also tested. The microorganisms were obtained from the Mycological laboratory, Institute for Biological Research "Sinisa Stanković", Serbia. Minimum inhibitory concentrations (MIC) were determined by a serial microdilution method and the rapid $p$-iodonitrotetrazolium violet (INT) colorimetric assay, following the protocol described by Soković et al. (2010) and Soković and van Griensven (2006). MICs were defined as the lowest extract concentration that inhibits the visible microbial growth (at the binocular microscope). Minimal bactericidal and fungicidal concentrations (MBC and MFC, respectively) were determined by measuring the lowest concentration that yielded no growth; therefore, MBC and MFC were defined as the lowest extract concentration required to kill the original inoculum. Five percent DMSO was used as a negative control. As positive controls, streptomycin and ampicillin were used for the antibacterial activity, while ketoconazole and bifonazole were used for the antifungal activity. The results were given as MICs, MBCs and MFCs in $\mathrm{mg} / \mathrm{mL}$.

\subsection{Chromatographic analysis of phenolic compounds}

Approximately $10 \mathrm{mg}$ of the dry extracts were redissolved in $2 \mathrm{~mL}$ of methanol/water $(20: 80, \mathrm{v} / \mathrm{v})$ and filtered through 0.22 $\mu \mathrm{m}$ disposable LC filter disks. The analysis was carried out in a Dionex Ultimate 3000 HPLC system (Thermo Scientific, San Jose, CA, USA) equipped with a diode array detector (DAD, at 280, 330, and $370 \mathrm{~nm}$ ) coupled to an electrospray ionization mass detector (ESI-MS) (Linear Ion Trap LTQ XL, Thermo Finnigan, San Jose, ca. USA). Separation was achieved with a Waters Spherisorb S3 ODS-2 C18 column $(3 \mu \mathrm{m}, 4.6 \mathrm{~mm} \times$ $150 \mathrm{~mm}$, Waters, Milford, MA, USA) thermostated at $35^{\circ} \mathrm{C}$. The solvents used were: (A) $0.1 \%$ formic acid in water, and (B) acetonitrile. The elution gradient established was isocratic: $15 \%$ B (5 min), $15 \%$ B to $20 \%$ B (5 min), $20-25 \%$ B (10 min), 25-35\% B (10 $\mathrm{min}), 35-50 \%$ B (10 $\mathrm{min})$, and re-equilibration of the column, using a flow rate of $0.5 \mathrm{~mL} / \mathrm{min}$. MS detection was performed in negative mode. Nitrogen served as the sheath gas ( $50 \mathrm{psi}$ ); the system was operated with a spray voltage of $5 \mathrm{kV}$, a source temperature of $325^{\circ} \mathrm{C}$, and a capillary voltage of $-20 \mathrm{~V}$. The tube lens offset was kept at a voltage of $-66 \mathrm{~V}$. The collision energy used was 35 (arbitrary units).
Chromatographic data were acquired and processed using Xcalibur software (Thermo Finnigan) (Bessada et al., 2016). Phenolic compounds were identified by comparing their retention times and UV-vis and mass spectra with those obtained from standard compounds, when available; otherwise, compounds were tentatively identified comparing the obtained information with available data reported in the literature. For quantitative analysis, a calibration curve for each available phenolic standard (Extrasynthèse, Genay, France) was constructed based on the UV signal (chlorogenic acid ( $\mathrm{y}=168823 \mathrm{x}$ - 161,172; $r^{2}=0.9999$; limit of detection (LOD) $=0.20 \mu \mathrm{g} / \mathrm{mL}$; limit of quantitation (LOQ) $=0.68 \mu \mathrm{g} / \mathrm{mL})$, ferulic acid $(\mathrm{y}=$ $633126 \mathrm{x}-185,462 ; r^{2}=0.999 ; \mathrm{LOD}=0.20 \mu \mathrm{g} / \mathrm{mL} ; \mathrm{LOQ}=1.01$ $\mu \mathrm{g} / \mathrm{mL}), p$-coumaric acid $\left(\mathrm{y}=301950 \mathrm{x}+6966.7 ; r^{2}=0.9999 ; \mathrm{LOD}\right.$ $=0.68 \mu \mathrm{g} / \mathrm{mL} ; \mathrm{LOQ}=1.61 \mu \mathrm{g} / \mathrm{mL})$, quercetin-3-O-glucoside $(\mathrm{y}=$ $34843 \mathrm{x}-160,173 ; r^{2}=0.9998 ; \mathrm{LOD}=0.21 \mu \mathrm{g} / \mathrm{mL} ; \mathrm{LOQ}=0.71$ $\mu \mathrm{g} / \mathrm{mL})$, and quercetin-3-O-rutinoside ( $\mathrm{y}=13343 \mathrm{x}+76,751 ; r^{2}$ $=0.9998 ; \mathrm{LOD}=0.18 \mu \mathrm{g} / \mathrm{mL} ; \mathrm{LOQ}=0.65 \mu \mathrm{g} / \mathrm{mL})$ ). The results were expressed as $\mathrm{mg}$ per $\mathrm{g}$ of extract.

\subsection{Statistical analysis}

Three independent samples were analysed and measured in triplicate. The results were expressed as mean \pm standard deviation. Statistical tests were performed at a $5 \%$ significance level using SPSS Statistics software (IBM SPSS Statistics for Windows, Version 22.0. Armonk, NY: IBM Corp.). Differences among samples were assessed using one-way analysis of variance (ANOVA). The fulfilment of the ANOVA requirements was tested by means of the Shapiro Wilk's and the Levene's tests. All dependent variables were compared using Tukey's HSD or Tamhane's T2 multiple comparison tests, when homoscedasticity was verified or not, respectively. In addition, a linear discriminant analysis (LDA) was performed to compare the different plant samples, applying the stepwise technique and the Wilk's $\lambda$ test with an F-value of 3.84 for entering and 2.71 for removal of variables. A Pearson's correlation was also run to assess correlations between compounds and antioxidant activities.

\section{Results and discussion}

\subsection{Morphological characteristics, dry weight and chlorophyll content}

The morphological characteristics of each tomato accession at the flowering and harvest seasons are described in Table 1. All plants reached their maximum height in the maturation season, which ranged from 72 to $183 \mathrm{~cm}$. In general, BPGV 12446 produced larger stems and leaves in both seasons, while the BPGV 12465 plants were smaller, as well as their leaves. Therefore, since the biomass of this accession was reduced, it was not pruned. Interestingly, despite the greater vegetative development of BPGV 12446, this accession did not produce fruits.

The tomato plants become dry and fibrous at the end of the growth cycle. As presented in Table 2, the dry matter content ranged from 10.0 to $11.7 \%$ in the pruning material and from 17.7 to $27 \%$ in end-of-cycle plants. In turn, the chlorophyll content seemed to be generally higher in the end-of-cycle plants than in the pruning material. Although the pruned shoots and leaves had a greener colour, the lower moisture content of the older plants justified the higher concentration of these photosynthetic pigments. The total chlorophyll content ranged 
Table 2 - Dry matter and chlorophyll content of the studied tomato crop remains.

\begin{tabular}{|c|c|c|c|}
\hline & $\begin{array}{l}\text { Dry weigh } \\
\text { (\%) }\end{array}$ & $\begin{array}{l}\text { Chlorophyll a } \\
\text { (mg/100 g fw) }\end{array}$ & $\begin{array}{l}\text { Chlorophyll b } \\
\text { (mg/100 g fw) }\end{array}$ \\
\hline \multicolumn{4}{|c|}{ Pruning material } \\
\hline BPGV 12260 & $11.7 \pm 0.6^{d}$ & $4.9 \pm 0.2^{h}$ & $3.9 \pm 0.4^{g}$ \\
\hline BPGV 12437 & $11.2 \pm 0.7^{d}$ & $5.797 \pm 0.004 \mathrm{~g}$ & $7.5 \pm 0.2 \mathrm{e}$ \\
\hline BPGV 12446 & $10.0 \pm 0.6^{d}$ & $6.00 \pm 0.02^{f}$ & $8.33 \pm 0.01^{c}$ \\
\hline BPGV 12906 & $10.3 \pm 0.6^{d}$ & $5.80 \pm 0.02 \mathrm{~g}$ & $8.3 \pm 0.2^{c}$ \\
\hline BPGV 13034 & $11.0 \pm 0.7^{d}$ & $5.58 \pm 0.02 \mathrm{~g}$ & $9.56 \pm 0.04^{b}$ \\
\hline \multicolumn{4}{|c|}{ End-of-cycle plants } \\
\hline BPGV 12260 & $22.6 \pm 0.9^{b}$ & $7.26 \pm 0.08^{e}$ & $8.39 \pm 0.09^{c}$ \\
\hline BPGV 12437 & $27 \pm 1^{a}$ & $9.49 \pm 0.02^{a}$ & $11.1 \pm 0.2^{\mathrm{a}}$ \\
\hline BPGV 12446 & $20.1 \pm 0.9^{c}$ & $7.45 \pm 0.08^{d}$ & $7.89 \pm 0.02^{d}$ \\
\hline BPGV 12465 & $24 \pm 1^{b}$ & $8.2 \pm 0.2^{b}$ & $7.96 \pm 0.07^{d}$ \\
\hline BPGV 12906 & $17.7 \pm 9^{c}$ & $7.18 \pm 0.05^{e}$ & $6.9 \pm 0.2^{f}$ \\
\hline BPGV 13034 & $23 \pm 1^{b}$ & $7.66 \pm 0.01^{c}$ & $7.4 \pm 0.1^{e}$ \\
\hline
\end{tabular}

The results are presented as mean \pm standard deviation. In each column, different letters correspond to significant differences $(p<0.05)$ between samples.

from 8.8 to $20.6 \mathrm{mg} / 100 \mathrm{~g}$ fw in the analysed tomato crop byproducts and was higher than the $4.22 \mathrm{mg} / \mathrm{g}$ dw previously quantified in stevia leaves (Bursać Kovačević et al., 2018) and the $6 \mathrm{mg} / 100 \mathrm{~g}$ fw reported in spinach, and lower than the 115 $\mathrm{mg} / 100 \mathrm{~g}$ fw found in spirulina (Hynstova et al., 2018). In a previous study performed with stems, leaves, and whole tomato plant, Silva-Beltrán et al. (2015) reported a positive correlation between chlorophyll content and antioxidant activity, as these natural pigments are able to reduce free radicals by acting as hydrogen donors.

In order to find a correlation between the morphological characteristics described in Table 1 with the dry matter and chlorophyll contents of each tomato accession, a LDA was performed and the spatial distribution of the sample markers according to the canonical discriminant function coefficients are shown in Fig. 1A. The two represented functions accounted for 50.2 and $22.8 \%$ of the total variance and provided a noticeable separation between markers corresponding to green pruning and end-of-cycle plant materials based mainly on morphological aspects and chlorophyll $b$ contents, respectively. Both functions were also able to discriminate samples based on dry matter and chlorophyll a contents. Thus, end-ofcycle plants of BPGV 12437 were distanced due to the higher chlorophyll and dry matter contents, while BPGV 12465 was projected due to the less biomass production.

\subsection{Total phenolics and flavonoids and antioxidant activity}

The extraction yields (extract weight) achieved with the solidliquid extractions made with $80 \%$ ethanol are presented in Table 3. The pruning material allowed obtaining higher extraction yields $(16-21 \%)$ than the end-of-cycle plants (8-14\%), a difference that can be justified by the fibrous consistency of the older plants. The obtained extracts were used to quantify the phenolic content and the antioxidant activities and may find many applications in the industrial sector, while the residue originated after filtration was discharged. However, it could be an interesting potential source of natural fibres (Galanakis, 2019) whose recovery may help to promote "zero waste".

The higher contents of phenolics and flavonoids were measured on the accessions BPGV 12437 (70.8 mg GAE/g extract and $30.9 \mathrm{mg} \mathrm{CE} / \mathrm{g}$ extract) and BPGV 13034 (69.0 mg GAE/g extract and $32.3 \mathrm{mg} \mathrm{CE} / \mathrm{g}$ extract), which also stand out for the $\mathrm{DPPH}^{\circ}$ scavenging activity and reducing power with $\mathrm{EC}_{50}$ values $\leq 1.04 \mathrm{mg} / \mathrm{mL}$ and $0.43 \mathrm{mg} / \mathrm{mL}$ (Table 3). In turn, the lowest phenolic and flavonoid levels and antioxidant activity were presented by the end-of-cycle plants of BPGV 12465. These results are somehow connected to those obtained previously for the fruits of the same table tomato accessions, with the BPGV 12437 and BPGV 12465 fruit extracts also leading to low $(3.7 \mathrm{mg} / \mathrm{mL})$ and high $(9.11 \mathrm{mg} / \mathrm{mL}) \mathrm{EC}_{50}$ values in the DPPH assay, respectively (Pinela et al., 2019). Nevertheless, the tomato crop by-products revealed a higher antioxidant activity than the respective fruits. It is also worth noting that the accessions BPGV 12446 and BPGV 12465 did not produced fruits or branches in enough auxiliary shoots to be pruned, respectively, agronomic aspects that seemed to be reflected in the antioxidant potential.

In a previous study, Silva-Beltrán et al. (2015) determined the total phenolic and flavonoid content of stem, root, leaf, and whole plant extracts from two tomato cultivars and attributed the highest levels (83.4-125.5 mg GAE/g extract and 33.0-61.9 $\mathrm{mg} \mathrm{QE} / \mathrm{g}$ extract, respectively) and antioxidant activity (measured by the DPPH, ABTS, and ORAC assays) to the leaf extracts, followed by the whole plant fraction. The authors also concluded that the roots are not an important reservoir of these compound. This discrepancy in relation to the results obtained in the present study could be related to the extraction method and solvent used to obtain the extracts and to the physiological state of the plant material, as well as to slight modifications in the quantification methods. In comparison with other plant by-products, slightly lower total phenolic levels (36.8-46.7 mg $\mathrm{GAE} / \mathrm{g}$ extract) were reported in mature leaves of sweet potato (Su et al., 2019) and a lower content (12.7 mg GAE/g extract) in olive leaves (Ferreira et al., 2007). Despite this, the olive leaf extract gave rise to comparable $\mathrm{EC}_{50}$ values $(0.91 \mathrm{mg} / \mathrm{mL})$ for the $\mathrm{DPPH}^{*}$ scavenging activity, but higher $(1.17 \mathrm{mg} / \mathrm{mL})$ for the reducing power, when compared to those obtained in the present study.

As shown in Table 3, none of the extracts of end-of-cycle plants showed antihemolytic activity at the tested concentrations, nor the one obtained with the pruning material of BPGV 12446 (which revealed relatively high $\mathrm{EC}_{50}$ values in the other two assays). The extract of BPGV 12906 was the most effective in protecting the sheep erythrocytes from the oxidative haemolysis caused the thermal decomposition of 

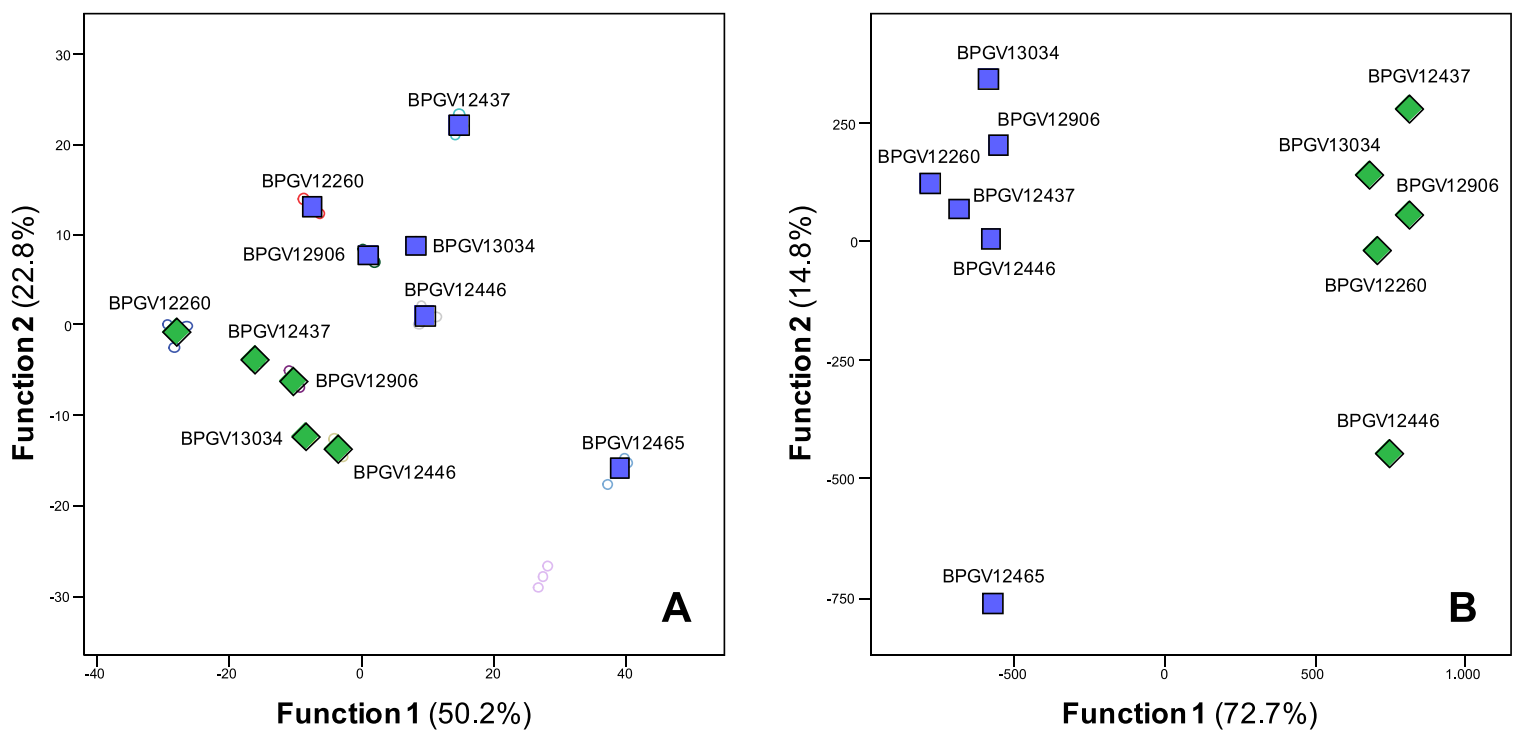

Fig. 1 - Spatial distribution of plant sample markers (pruning material $\diamond$ and end-of-cycle plants $\square$ ) following the distribution set by the canonical discriminant function coefficients, (A) when considering the morphological characteristics and the dry matter and chlorophyll contents and (B) when considering all the studied variables, except antimicrobial activity.

Table 3 - Extraction yield, total phenolic and flavonoid contents, and antioxidant and antihaemolytic activities of the extract of the studied tomato crop remains.

\begin{tabular}{|c|c|c|c|c|c|c|}
\hline & $\begin{array}{l}\text { Extraction } \\
\text { yield } \\
\text { (\%, g extract/g } \\
\text { sample) }\end{array}$ & $\begin{array}{l}\text { Total } \\
\text { phenolics } \\
\text { (mg GAE/g } \\
\text { extract) }\end{array}$ & $\begin{array}{l}\text { Total } \\
\text { flavonoids } \\
\text { (mg CE/g } \\
\text { extract) }\end{array}$ & $\begin{array}{l}\text { Scavenging } \\
\text { activity } \\
\left(\mathrm{EC}_{50} \text { values, }\right. \\
\mathrm{mg} / \mathrm{mL})\end{array}$ & $\begin{array}{l}\text { Reducing } \\
\text { power } \\
\left(\mathrm{EC}_{50} \text { values, }\right. \\
\mathrm{mg} / \mathrm{mL})\end{array}$ & $\begin{array}{l}\text { Antihemolytic } \\
\text { activity } \\
\text { (IC } \mathrm{I}_{50} \text { values, } \\
\mu \mathrm{g} / \mathrm{mL} \text { ) }\end{array}$ \\
\hline \multicolumn{7}{|c|}{ Pruning material } \\
\hline BPGV 12260 & $16 \pm 1^{b, c}$ & $60.7 \pm 0.5^{c, b}$ & $27.2 \pm 0.4^{c}$ & $1.24 \pm 0.03^{c}$ & $0.56 \pm 0.01^{g}$ & $91 \pm 5^{a}$ \\
\hline BPGV 12437 & $20 \pm 2^{a, b}$ & $70.8 \pm 0.4^{a}$ & $30.9 \pm 0.4^{b}$ & $0.77 \pm 0.04^{f}$ & $0.36 \pm 0.01^{j}$ & $30.8 \pm 0.6^{b}$ \\
\hline BPGV 12446 & $21 \pm 2^{a}$ & $48.4 \pm 0.1^{e}$ & $19.6 \pm 0.4^{\mathrm{f}}$ & $1.86 \pm 0.04^{b}$ & $0.675 \pm 0.004 \mathrm{e}$ & na \\
\hline BPGV 12906 & $20 \pm 2^{a}$ & $56.2 \pm 0.7^{c, d}$ & $28.1 \pm 0.3^{c}$ & $1.24 \pm 0.06^{c}$ & $0.46 \pm 0.07^{h}$ & $22.4 \pm 0.3^{c}$ \\
\hline BPGV 13034 & $16 \pm 1^{b, c}$ & $69.0 \pm 0.4^{a}$ & $32.3 \pm 0.3^{a}$ & $1.04 \pm 0.02^{e}$ & $0.43 \pm 0.01^{i}$ & $31.0 \pm 0.4^{b}$ \\
\hline \multicolumn{7}{|c|}{ End-of-cycle plants } \\
\hline BPGV 12260 & $11.5 \pm 0.9 \mathrm{~d}, \mathrm{e}$ & $55.4 \pm 0.3^{d}$ & $23.3 \pm 0.8^{e}$ & $1.04 \pm 0.03^{e}$ & $0.763 \pm 0.003^{d}$ & na \\
\hline BPGV 12437 & $8.0 \pm 0.6^{\mathrm{e}}$ & $59 \pm 2^{c, d}$ & $24.9 \pm 0.7^{d}$ & $1.13 \pm 0.04^{d}$ & $0.583 \pm 0.005^{f}$ & na \\
\hline BPGV 12446 & $11.5 \pm 0.9 \mathrm{~d}, \mathrm{e}$ & $56 \pm 2^{c, d}$ & $23.8 \pm 0.1 \mathrm{~d}, \mathrm{e}$ & $1.17 \pm 0.03^{d}$ & $0.67 \pm 0.02^{e}$ & na \\
\hline BPGV 12465 & $10.3 \pm 0.8^{e}$ & $39 \pm 2^{f}$ & $21 \pm 1^{\mathrm{f}}$ & $2.4 \pm 0.02^{a}$ & $0.853 \pm 0.003^{a}$ & na \\
\hline BPGV 12906 & $14 \pm 1^{c, d}$ & $57 \pm 1^{d}$ & $22 \pm 1$ e,f & $1.25 \pm 0.01^{c}$ & $0.797 \pm 0.07^{c}$ & na \\
\hline BPGV 13034 & $10.7 \pm 0.9^{e}$ & $64 \pm 2^{b}$ & $18.1 \pm 0.1^{g}$ & $1.04 \pm 0.03^{e}$ & $0.83 \pm 0.01^{b}$ & na \\
\hline Trolox & - & - & - & $0.043 \pm 0.002$ & $0.029 \pm 0.003$ & $19.6 \pm 0.7^{c}$ \\
\hline
\end{tabular}

the free-radical initiator AAPH, since $22.4 \mu \mathrm{g} / \mathrm{mL}$ of extract were enough to preserved $50 \%$ of the erythrocyte population intact for a $\Delta t$ of $60 \mathrm{~min}$. This result was comparable to that obtained with the commercial antioxidant trolox used as a positive control. The extracts of the accessions BPGV 12437 and BPGV 12906 presented a similar antihaemolytic activity $\left(\mathrm{IC}_{50}=\sim 31 \mu \mathrm{g} / \mathrm{mL}\right)$. This bioassay offers near-in vivo conditions as the free radicals generated in the in vitro system are also found in the human organism (Takebayashi et al., 2012), thus being useful for measuring the antioxidant activity of natural extracts.

Many studies have already reported strong correlations between phenolic compounds and antioxidant activities (Alrashdi et al., 2017; Mohamed et al., 2016, 2014; Pinela et al., 2018; Silva-Beltrán et al., 2015; Turumtay et al., 2014). The structure of these phytochemicals has been related to their radical-scavenging and metal-chelating activities (Pinela et al., 2016). Herein, a Pearson's analysis indicated very strong correlations $(p<0.001)$ between total phenolics and DPPH scavenging activity $(r=-0.901)$, and total flavonoids and quercetin-3-O-rutinoside with reducing power $(r=-0.904$ and -0.901 , respectively). Strong correlations $(p<0.001)$ were also observed between 5-O-feruloylquinic acid $(r=-0.833)$ and kaempferol-3-O-rutinoside $(r=-0.797)$ with reducing power. These significant correlations were negative, because the lower the $\mathrm{EC}_{50}$ values, the higher the antioxidant activity of the extracts.

\subsection{Antimicrobial activity}

Plant extracts have been used to prevent food poisoning diseases and preserve formulated foods due in part to their antimicrobial properties (Barakat et al., 2020; Takwa et al., 2018). Therefore, the tomato plant extracts were tested 
Table 4 - Antibacterial activity of the extracts of the studied tomato crop remains and positive controls, streptomycin and ampicillin.

\begin{tabular}{|c|c|c|c|c|c|c|c|}
\hline & & Bacillus cereus & $\begin{array}{l}\text { Staphylococcus } \\
\text { aureus }\end{array}$ & $\begin{array}{l}\text { Listeria } \\
\text { monocytogenes }\end{array}$ & Escherichia coli & $\begin{array}{l}\text { Enterobacter } \\
\text { cloacae }\end{array}$ & $\begin{array}{l}\text { Salmonella } \\
\text { typhimurium }\end{array}$ \\
\hline \multicolumn{8}{|c|}{ Pruning material } \\
\hline \multirow[t]{2}{*}{ BPGV 12260} & MIC & 0.45 & 0.90 & 0.60 & 0.90 & 0.30 & 0.30 \\
\hline & $\mathrm{MBC}$ & 0.60 & 1.20 & 0.90 & 1.20 & 0.60 & 0.60 \\
\hline \multirow[t]{2}{*}{ BPGV 12437} & MIC & na & na & 0.30 & 0.60 & 0.30 & 0.30 \\
\hline & $\mathrm{MBC}$ & na & na & 0.60 & 1.20 & 0.60 & 0.60 \\
\hline \multirow[t]{2}{*}{ BPGV 12446} & MIC & 0.15 & 0.60 & 0.30 & 0.90 & 0.15 & 0.30 \\
\hline & $\mathrm{MBC}$ & 0.30 & 0.90 & 0.60 & 1.20 & 0.30 & 0.60 \\
\hline \multirow[t]{2}{*}{ BPGV 12906} & MIC & 0.30 & 0.60 & 0.30 & 0.60 & 0.30 & 0.30 \\
\hline & $\mathrm{MBC}$ & 0.60 & 0.90 & 0.60 & 0.90 & 0.60 & 0.60 \\
\hline \multirow[t]{2}{*}{ BPGV 13034} & MIC & 0.20 & 0.60 & 0.60 & 0.60 & 0.60 & 0.30 \\
\hline & $\mathrm{MBC}$ & 0.30 & 1.20 & 1.20 & 1.20 & 0.90 & 0.60 \\
\hline \multicolumn{8}{|c|}{ End-of-cycle plants } \\
\hline \multirow[t]{2}{*}{ BPGV 12260} & MIC & 0.20 & 0.20 & 0.30 & 0.60 & 0.30 & 0.30 \\
\hline & $\mathrm{MBC}$ & 0.30 & 0.45 & 0.60 & 0.90 & 0.60 & 0.60 \\
\hline \multirow[t]{2}{*}{ BPGV 12437} & MIC & 0.30 & 0.60 & 0.30 & 0.90 & 0.30 & 0.30 \\
\hline & $\mathrm{MBC}$ & 0.60 & 1.20 & 0.60 & 1.20 & 0.60 & 0.60 \\
\hline \multirow[t]{2}{*}{ BPGV 12446} & MIC & 0.60 & 0.90 & 0.45 & 0.90 & 0.30 & 0.30 \\
\hline & $\mathrm{MBC}$ & 0.90 & 1.20 & 0.60 & 1.20 & 0.60 & 0.60 \\
\hline \multirow[t]{2}{*}{ BPGV 12465} & MIC & 0.60 & 0.60 & 0.60 & 0.90 & 0.60 & 0.45 \\
\hline & $\mathrm{MBC}$ & 0.90 & 1.20 & 0.90 & 1.20 & 0.90 & 0.90 \\
\hline \multirow[t]{2}{*}{ BPGV 12906} & MIC & 0.45 & 0.60 & 0.60 & 0.90 & 0.45 & 0.30 \\
\hline & $\mathrm{MBC}$ & 0.90 & 0.90 & 0.90 & 1.20 & 0.60 & 0.60 \\
\hline \multirow[t]{2}{*}{ BPGV 13034} & MIC & 0.45 & 0.60 & 0.30 & 0.60 & 0.30 & 0.30 \\
\hline & $\mathrm{MBC}$ & 0.60 & 0.90 & 0.60 & 1.20 & 0.60 & 0.60 \\
\hline \multirow[t]{2}{*}{ Streptomycin } & MIC & 0.10 & 0.04 & 0.20 & 0.20 & 0.20 & 0.20 \\
\hline & $\mathrm{MBC}$ & 0.20 & 0.10 & 0.30 & 0.30 & 0.30 & 0.30 \\
\hline \multirow[t]{2}{*}{ Ampicillin } & MIC & 0.25 & 0.25 & 0.40 & 0.40 & 0.25 & 0.75 \\
\hline & $\mathrm{MBC}$ & 0.40 & 0.45 & 0.50 & 0.50 & 0.50 & 1.20 \\
\hline
\end{tabular}

MIC: minimum inhibitory concentration (mg/mL); MBC: minimum bactericidal concentration (mg/mL); na: not activity

against Gram-positive (Bacillus cereus, Staphylococcus aureus, and Listeria monocytogenes) and Gram-negative (Escherichia coli, Enterobacter cloacae, and Salmonella typhimurium) bacteria and the results are presented in Table 4 . The tested extracts revealed capacity to inhibit $S$. typhimurium, an important causative agent of non-typhoidal salmonellosis in humans, with MIC values close to that of streptomycin $(0.20 \mathrm{mg} / \mathrm{mL})$ and lower to that of ampicillin $(0.70 \mathrm{mg} / \mathrm{mL})$. The extracts were also more efficient than ampicillin in killing this Gramnegative bacterium ( $\mathrm{MBC} \leq 0.9 \mathrm{mg} / \mathrm{mL}$ ). Although effective, the BPGV 12465 extract gave slightly higher MIC $(0.45 \mathrm{mg} / \mathrm{mL})$ and $\mathrm{MBC}(0.9 \mathrm{mg} / \mathrm{mL})$ values than the other extracts against S. typhimurium, but it was less active against the other tested bacteria.

The extracts of the BPGV 12446 and BPGV 13034 pruning materials and BPGV 12260 end-of-cycle plants revealed better antimicrobial activity than ampicillin against $B$. cereus, with MIC of $0.15-0.2 \mathrm{mg} / \mathrm{mL}$ and $\mathrm{MBC}$ of $0.3 \mathrm{mg} / \mathrm{mL}$, respectively (Table 5). The lastly mentioned extract was also the most effective against $S$. aureus, with 0.20 and $0.45 \mathrm{mg} / \mathrm{mL}$ being enough to inhibit and kill this foodborne pathogenic bacterium. Six of the extracts tested against $L$. monocytogenes showed a MIC $(0.3$ $\mathrm{mg} / \mathrm{mL}$ ) between the values obtained for the antibiotics used as positive control $(0.2-0.4 \mathrm{mg} / \mathrm{mL})$. In general, it was easier to inhibit than to kill the selected microorganisms and E. coli was the most resistant.

The antibacterial activity of tomato plant extracts was previously tested by Silva-Beltrán et al. (2015) against E. coli, S. typhimurium, S. aureus, and Listeria ivanovii. The obtained MIC values ranged from 3.1 to $>25 \mathrm{mg} / \mathrm{mL}$ and were much higher than those in the present study. The authors correlated the polyphenols content with the antimicrobial activity. In fact, the hydroxyl groups of polyphenols can interact with the cell membrane of bacteria and cause their destruction. Its position in the aromatic ring and the length of the saturated side chain of phenolic acids are structural features that can also increase the antimicrobial activity (Gyawali and Ibrahim, 2014). Silva-Beltrán and co-workers also reported that the bacterial susceptibility may have been increased by glycoalkaloids and suggested their possible synergistic effect with polyphenols.

Table 5 also shows the results of the extracts activity against the microfungi Aspergillus fumigatus, A. ochraceus, A. niger, Penicillium ochrochloron, $P$. funiculosum, and P. verrucosum var. cyclopium. In general, the tested extracts did not show as good antifungal activity as antimicrobial. Additionally, some of them had no activity (na), especially those prepared from green pruning material. Among these samples, the best results were achieved against $P$. funiculosum as some extracts (BPGV 12260, BPGV 12446, BPGV 12906, and BPGV 13034) had MIC/MBC values lower than those of ketoconazole (2.50 and $3.50 \mathrm{mg} / \mathrm{mL}$, respectively). Interestingly, the extracts of BPGV 12437 and BPGV 12465 end-of-cycle plants, which contained just traces of phenolic compounds (Table 6), had no activity against this microorganism or against A. ochraceus and A. niger.

Kim et al. (Kim et al., 2019) studied the activity of tomato leaf extracts against fungi and oomycetes pathogenic to tomato plants, among which Rhizoctonia solani was the most susceptible to acetonic leaf extract, with a MIC $<0.31 \mathrm{mg} / \mathrm{mL}$, and suggested the involvement of phenolic acids (caffeic acid) and fatty acids (linolenic acid) in this bioactivity. Therefore, since no significant correlations were found between pheno- 
Table 5 - Antifungal activity of the extracts of the studied tomato crop remains and positive controls, ketoconazole and

bifonazole.

\begin{tabular}{|c|c|c|c|c|c|c|c|}
\hline & & $\begin{array}{l}\text { Aspergillus } \\
\text { fumigatus }\end{array}$ & $\begin{array}{l}\text { Aspergillus } \\
\text { ochraceus }\end{array}$ & $\begin{array}{l}\text { Aspergillus } \\
\text { niger }\end{array}$ & $\begin{array}{l}\text { Penicillium } \\
\text { ochrochloron }\end{array}$ & $\begin{array}{l}\text { Penicillium } \\
\text { funiculosum }\end{array}$ & $\begin{array}{l}\text { Penicillium } \\
\text { verrucosum var. } \\
\text { cyclopium }\end{array}$ \\
\hline \multicolumn{8}{|c|}{ Pruning material } \\
\hline \multirow[t]{2}{*}{ BPGV 12260} & MIC & na & na & na & na & na & na \\
\hline & MFC & na & na & na & na & na & na \\
\hline \multirow[t]{2}{*}{ BPGV 12437} & MIC & 0.45 & na & na & na & 0.90 & 0.45 \\
\hline & MFC & 1.20 & na & na & na & 1.20 & 1.20 \\
\hline \multirow[t]{2}{*}{ BPGV 12446} & MIC & 0.90 & 0.90 & na & 0.60 & na & 0.45 \\
\hline & MFC & 1.20 & 1.20 & na & 0.90 & na & 0.90 \\
\hline \multirow[t]{2}{*}{ BPGV 12906} & MIC & 0.45 & na & na & na & na & na \\
\hline & MFC & 0.90 & na & na & na & na & na \\
\hline \multirow[t]{2}{*}{ BPGV 13034} & MIC & 0.60 & na & na & na & na & 0.90 \\
\hline & MFC & 0.90 & na & na & na & na & 1.20 \\
\hline \multicolumn{8}{|c|}{ End-of-cycle plants } \\
\hline \multirow[t]{2}{*}{ BPGV 12260} & MIC & 0.60 & 0.60 & 0.90 & 0.60 & 0.60 & 0.60 \\
\hline & MFC & 0.90 & 0.90 & 1.20 & 1.20 & 1.20 & 0.90 \\
\hline \multirow[t]{2}{*}{ BPGV 12437} & MIC & na & na & na & 0.90 & na & 0.90 \\
\hline & MFC & na & na & na & 1.20 & na & 1.20 \\
\hline \multirow[t]{2}{*}{ BPGV 12446} & MIC & 0.90 & 0.90 & na & 0.60 & 0.45 & 0.60 \\
\hline & MFC & 1.20 & 1.20 & na & 0.90 & 0.90 & 0.90 \\
\hline \multirow[t]{2}{*}{ BPGV 12465} & MIC & 0.90 & na & na & na & na & 0.90 \\
\hline & MFC & 1.20 & na & na & na & na & 1.20 \\
\hline \multirow[t]{2}{*}{ BPGV 12906} & MIC & 0.60 & 0.60 & 0.90 & 0.45 & 0.45 & 0.30 \\
\hline & MFC & 0.90 & 0.90 & 1.20 & 0.90 & 0.90 & 0.60 \\
\hline \multirow[t]{2}{*}{ BPGV 13034} & MIC & 0.60 & 0.60 & 0.90 & 0.60 & 0.90 & 0.90 \\
\hline & MFC & 0.90 & 0.90 & 1.20 & 0.90 & 1.20 & 1.20 \\
\hline \multirow[t]{2}{*}{ Ketoconazole } & MIC & 0.25 & 0.20 & 0.20 & 0.20 & 2.50 & 0.20 \\
\hline & MFC & 0.50 & 0.50 & 0.50 & 0.50 & 3.50 & 0.30 \\
\hline \multirow[t]{2}{*}{ Bifonazole } & MIC & 0.15 & 0.10 & 0.15 & 0.20 & 0.20 & 0.10 \\
\hline & MFC & 0.20 & 0.20 & 0.20 & 0.25 & 0.25 & 0.20 \\
\hline
\end{tabular}

lic compounds and antimicrobial activity in the present study, we also believe that compounds other than phenolics may be involved in the antibacterial and antifungal effects of the extracts, such as glycoalkaloids, organic acids, and fatty acids, and it could also justify the best performance of the end-ofcycle plant material.

It is also worth noting the "bifunctionality" of some extracts capable of exerting antioxidant and also antimicrobial effects. In the particular case of BPGV 12906 and BPGV 13034, minimum extract concentrations of $1.20 \mathrm{mg} / \mathrm{mL}$ will be necessary to achieve the antioxidant-antimicrobial effect. This bifunctionality can be attributed to the different extract constituents, such as the polyphenols identified in this study, but also to other compounds that may be present such as glycoalkaloids, organic acids, and fatty acids. In addition, the same compound can display various bioactive effects due to the features of its chemical structure (Gyawali and Ibrahim, 2014). Synergistic or antagonistic effects may also occur between the extract constituents.

\subsection{Phenolic composition}

The profile in phenolic compounds of the hydroethanolic extracts of the tomato crop residues was characterized by HPLC-DAD-ESI/MS ${ }^{n}$. As illustrative case, the profile of BPGV 12437 pruning material is shown in Fig. 2. Data related to their identification are presented in Table 6, namely the retention time, $\lambda_{\max }$ in the UV-vis region, pseudomolecular ion, and major fragment ions in $\mathrm{MS}^{2}$. The detected compounds were grouped into phenolic acids ( $p$-coumaric acid hexoside, 5-O-caffeoylquinic acid, 5-p-coumaroylquinic acid, and 5-O-feruloylquinic acid) and flavonoids, more specifically flavonols (quercetin-pentosyl-rutinoside, quercetin-3O-rutinoside (rutin), quercetin-dexosyhexosyl-hexoside, and kaempferol-3-O-rutinoside), these predominating over phenolic acid (Fig. 3). Most of these compounds have been reported in tomato leaves (Figueiredo-González et al., 2016; Larbat et al., 2014; Taveira et al., 2012) and fruits (Barros et al., 2012; Pinela et al., 2019), so their identification was made by interpreting the chromatographic data with information available in the literature.

The levels of individual phenolic acids and flavonoids presented in Table 6 were added to obtain the total contents shown in Fig. 3, where it is possible to observe that the phenolic compounds were more abundant in the pruning material, with levels ranging from $10.2 \pm 0.2$ $\mathrm{mg} / \mathrm{g}$ extract in BPGV 12446 to $23.4 \pm 0.6 \mathrm{mg} / \mathrm{g}$ extract in BPGV 12437. In fact, some phenolic compounds were not detected (nd) or detected in trace amounts (tr) in most of the extracts obtained from plants at the end of the grow cycle (Table 6), hence the lower contents showed in Fig. 3. Quercetin-3-O-rutinoside was the major compound with concentrations of 5.8-17 mg/g extract in pruning materials and $2.01-7.07 \mathrm{mg} / \mathrm{g}$ extract in plant remains. It was already reported as the major flavonoid in leaves of tomato varieties and cultivar (Larbat et al., 2014; Taveira et al., 2012). This compound together with quercetin pentosylrutinoside were also found as predominant flavonoids in tomato fruits (Barros et al., 2012; Pinela et al., 2019). Quercetin3-O-rutinoside has been reported to exert a wide range 


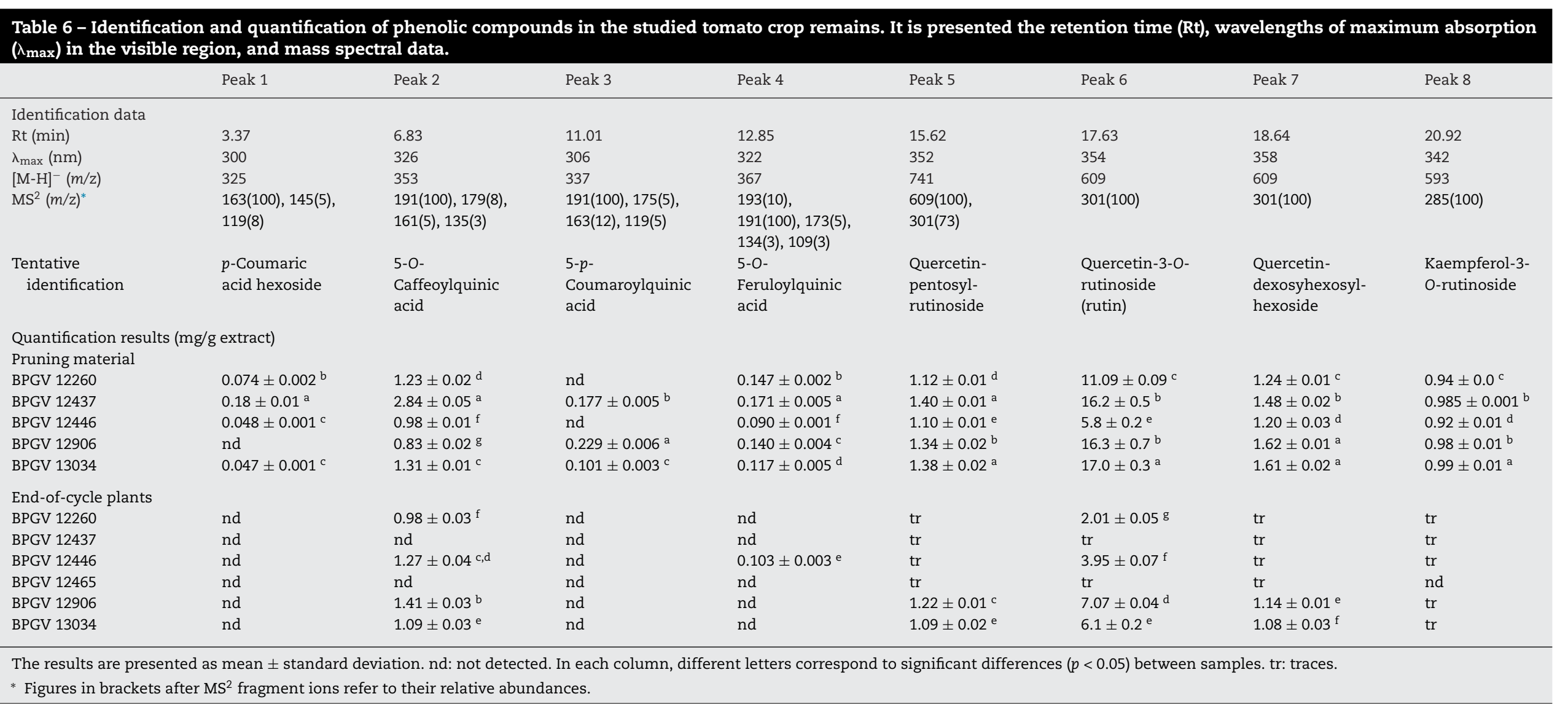




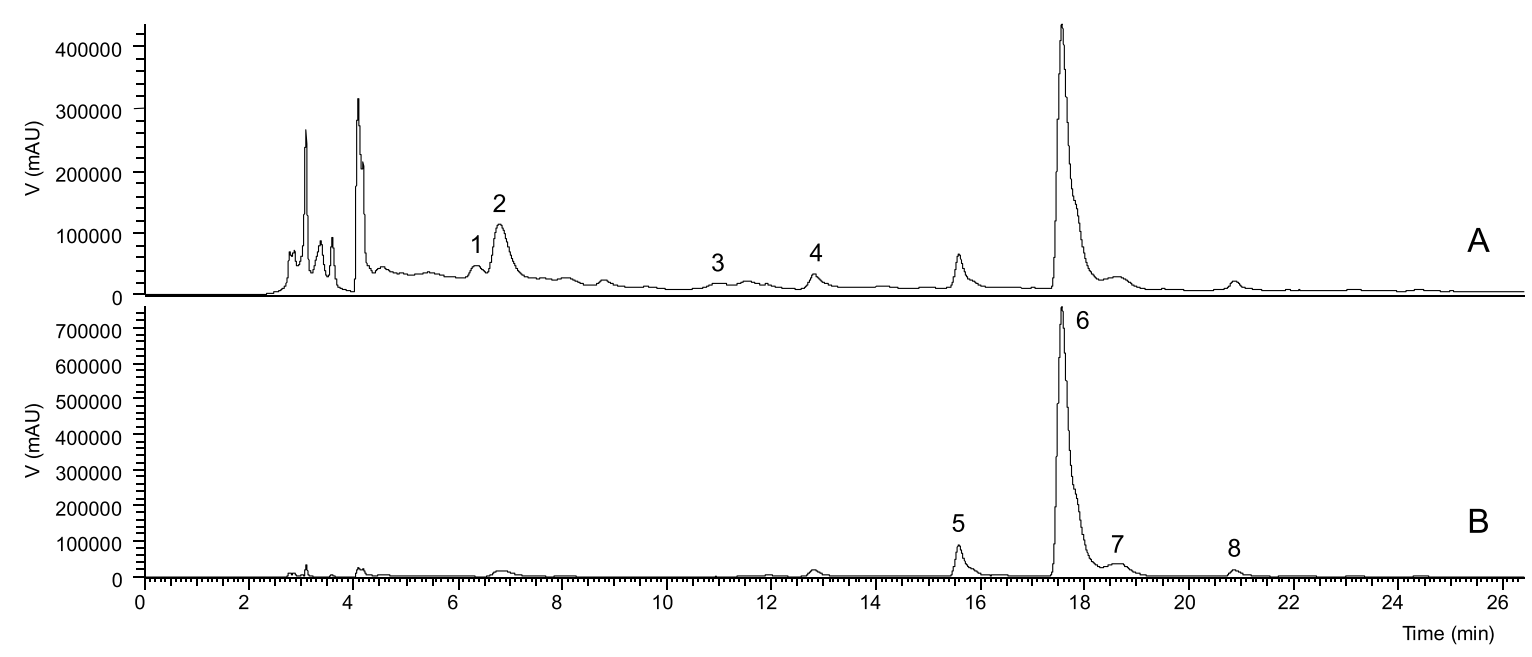

Fig. 2 - HPLC phenolic profile of the hydroethanolic extract of BPGV 12437 pruning material, extracted at (A) $280 \mathrm{~nm}$ and (B) $370 \mathrm{~nm}$.

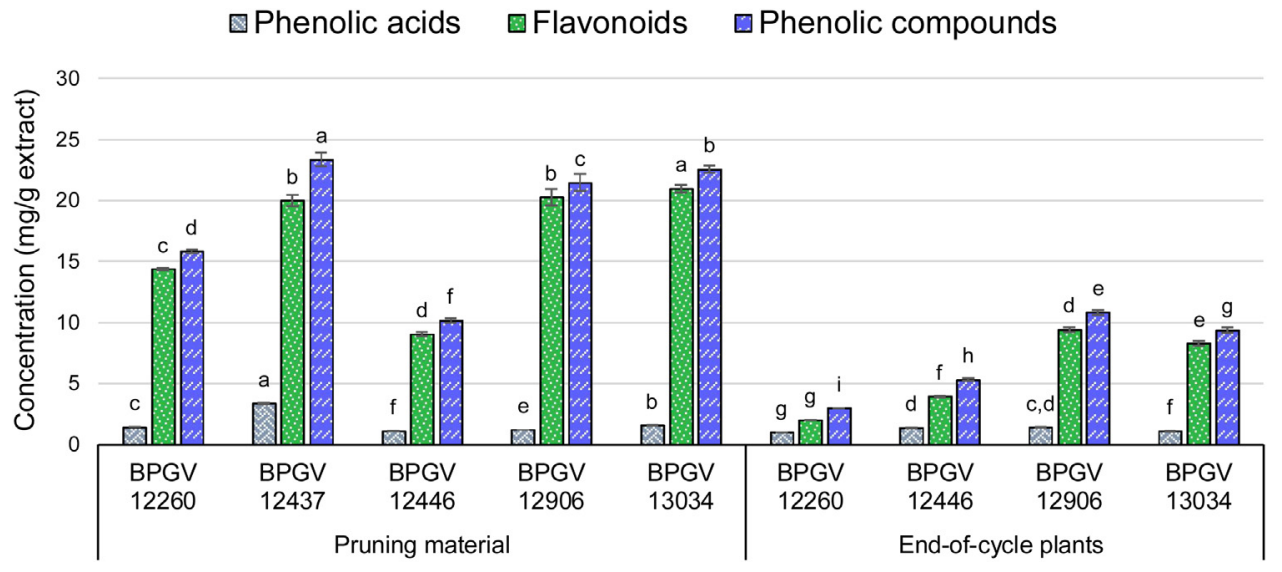

Fig. 3 - Phenolic acid and flavonoid contents in the tomato crop residues resulting from the sum of the individual phenolic compounds in Table 6. For each phenolic group, different letters over bars indicate statistically significant differences $(p<$ $0.05)$ between samples.

of biological activities including antioxidant, antimicrobial, anti-inflammatory, and hypolipidemic effects (Gullón et al., 2017).

Among the pruning material, BPGV 13034 was particularly rich in flavonoids ( $21 \pm 0.3 \mathrm{mg} / \mathrm{g}$ extract), while BPGV $12437 \mathrm{had}$ the higher amounts of phenolic acids $(3.37 \pm 0.07 \mathrm{mg} / \mathrm{g}$ extract) (Fig. 3 and Table 6). The 5-O-caffeoylquinic acid was the most abundant organic acids and, in BPGV 12906 and BPGV 13034, it was detected in higher quantities in the oldest plant tissues (Table 6). In almost all accessions, 5-p-coumaroylquinic and 5-O-feruloylquinic acids were not detected in the plant remains. The observed quantitative differences in the phenolic profile of the studied tomato accessions could be related to cultural practices, such as developmental stage, and genetic differences.

It is interesting to mention that the accessions BPGV 12437 and BPGV 13034 revealed high levels of phenolics and flavonoids in both colorimetric (Table 3) and chromatographic (Fig. 3 and Table 6) methods. In addition, among green pruning, BPGV 12446 showed low concentrations of individual phenolic compounds (Fig. 3) and also low responses in the Folin-Ciocalteu and aluminium chloride methods and in vitro antioxidant assays (Table 3). In turn, among end-of-cycle plants, BPGV 12465 contained the lowest levels of total phenolics and only traces of individual compounds, as well as low antioxidant activity. These secondary metabolites are well-known for their biological and pharmacological effects (Naveed et al., 2018; Testai, 2015) and could be linked to the observed antioxidant activity. Therefore, the exploitation of tomato plant extracts as natural ingredients or source of bioactive compounds for the food and pharmaceutical industries is proposed, but their processing for microorganisms inactivation is necessary to ensure its safety and could be achieved using sonication treatments (Zinoviadou et al., 2015). In future studies, it would be interesting to explore non-conventional methods like pulsed electric technologies and pressurized liquids to improve the extraction of the phenolic compounds identified in the tomato plant by-products, since these eco-friendly processes have been described as presenting advantages in terms of yield and selectivity (Barba et al., 2015; Bursać Kovačević et al., 2018; Deng et al., 2015).

\subsection{Linear discriminant analysis}

A LDA was performed to assess the magnitude of the differences between the dependent variables discussed above (except antimicrobial activity). The two functions represented in Fig. 1B accounted for $87.5 \%$ of the total variance. Function 1 justified $72.7 \%$ of the observed vari- 
ance and provided an obvious separation between pruning material and end-of-cycle plants, being mainly correlated with differences in the concentration of phenolic compounds (sum of individual compounds), particularly 5-Oferuloylquinic acid, kaempferol-3-O-rutinoside and quercetinpentosyl-rutinoside, and chlorophyll $a$. In turn, function 2 justified $14.8 \%$ of the variance and was most correlated with $\mathrm{DPPH}^{*}$ scavenging activity, reducing power, antihaemolytic activity, and 5-O-caffeoylquinic acid contents. Thus, this function provided a clear separation of BPGV 12465 and also BPGV 12446 from the other samples in the group end-of-cycle plants and pruning material, respectively, as these had the highest $\mathrm{EC}_{50}$ values and not activity in the antihaemolytic assay.

\section{Conclusion}

Green pruning and end-of-cycle plant materials were characterized for their composition in chlorophylls and phenolic compounds, and antioxidant and antimicrobial activities. The chlorophyll content was higher in plants at the end of the vegetative cycle, probably due to a concentration effect promoted by water loss. The older plants showed a fibrous appearance that may be related to the lower extraction yields achieved with these samples. The HPLC-DAD-ESI/MS ${ }^{n}$ analysis allowed identifying 4 phenolic acids and 4 flavonoids, with prevalence of quercetin-3-0-rutinoside. The extracts also had antioxidant and antihemolytic activity, especially those produced from pruning tissues. Despite the low activity against the tested microfungi, some extracts had ability to inhibit and kill some bacteria, including S. typhimurium, L. monocytogenes, B. cereus, and E. cloacae, with MIC values lower than those of the antibiotic ampicillin. While phenolic compounds were correlated with antioxidant activity, no correlations were found between these phytochemical and antimicrobial activity, which suggests the involvement of other extract constituents. Overall, it was interesting to conclude that table tomato crop remains, currently with no commercial value, could be valorised as sustainable sources of bioactive phenolic compounds and extracts with antioxidant and antibacterial activities for application in the agri-food and pharmaceutical sectors.

\section{Declaration of interests}

The authors declare that they have no known competing financial interests or personal relationships that could have appeared to influence the work reported in this paper.

\section{Acknowledgements}

The authors are grateful to the Foundation for Science and Technology (FCT, Portugal) for financial support through national funds FCT/MCTES to CIMO (UIDB/00690/2020). J. Pinela and L. Barros thank their research contracts (national funding by FCT, P.I., through the institutional scientific employment program-contract). M. Añibarro-Ortega thanks his grant to the project Mobilizador ValorNatural: Norte-01-0247-FEDER-024479. The authors are grateful to FEDER-Interreg España-Portugal programmefor financial support through the project 0377_Iberphenol_6_E. This work was also supported by the Ministry of Education, Science and Technological Development of Republic of Serbia (451-03-68/2020-14/200007). To the PEPAC Program (2015) for supporting V. Martins training stage at the BPGV, Braga, Portugal.

\section{References}

Alrashdi, A.M.A., Al-Qurashi, A.D., Awad, M.A., Mohamed, S.A., Al-rashdi, A.A., 2017. Quality, antioxidant compounds, antioxidant capacity and enzymes activity of 'El-Bayadi' table grapes at harvest as affected by preharvest salicylic acid and gibberellic acid spray. Sci. Hortic. 220, 243-249.

Barakat, A.Z., Hamed, A.R., Bassuiny, R.I., Abdel-Aty, A.M., Mohamed, S.A., 2020. Date palm and saw palmetto seeds functional properties: antioxidant, anti-inflammatory and antimicrobial activities. J. Food Meas. Charact. 14, 1064-1072.

Barba, F.J., Galanakis, C.M., Esteve, M.J., Frigola, A., Vorobiev, E., 2015. Potential use of pulsed electric technologies and ultrasounds to improve the recovery of high-added value compounds from blackberries. J. Food Eng. 167, 38-44.

Barros, L., Carvalho, A.M., Morais, J.S., Ferreira, I.C.F.R., 2010. Strawberry-tree, blackthorn and rose fruits: detailed characterisation in nutrients and phytochemicals with antioxidant properties. Food Chem. 120, 247-254.

Barros, L., Dueñas, M., Pinela, J., Carvalho, A.M., Buelga, C.S., Ferreira, I.C.F.R., 2012. Characterization and quantification of phenolic compounds in four tomato (Lycopersicon esculentum L.) farmers' varieties in Northeastern Portugal homegardens. Plant Foods Hum. Nutr. 67, 229-234.

Bessada, S.M.F., Barreira, J.C.M., Barros, L., Ferreira, I.C.F.R., Oliveira, M.B.P.P., 2016. Phenolic profile and antioxidant activity of Coleostephus myconis (L.) Rchb.f.: an underexploited and highly disseminated species. Ind. Crops Prod. 89, 45-51.

Bursać Kovačević, D., Barba, F.J., Granato, D., Galanakis, C.M., Herceg, Z., Dragović-Uzelac, V., Putnik, P., 2018. Pressurized hot water extraction (PHWE) for the green recovery of bioactive compounds and steviol glycosides from Stevia rebaudiana Bertoni leaves. Food Chem. 254, 150-157.

Deng, Q., Zinoviadou, K.G., Galanakis, C.M., Orlien, V., Grimi, N., Vorobiev, E., Lebovka, N., Barba, F.J., 2015. The effects of conventional and non-conventional processing on glucosinolates and its derived forms, isothiocyanates: extraction, degradation, and applications. Food Eng. Rev. 7, 357-381.

European Commission, 2019. The Tomato Market in the EU: Vol 1: Production, Areas and Yields. FWG - Forecast Working Group for Tomatoes.

FAO, 2014. Genebank Standards for Plant Genetic Resources for Food and Agriculture. Food and Agriculture Organization of the United Nations, Rome (Italy)

FAOSTAT, 2019. FAOSTAT Online Database [WWW Document]. FAO, URL http://www.fao.org/faostat/en/?\#data/QC (Accessed 28 January 2019).

Ferreira, I.C.F.R., Barros, L., Soares, M.E., Bastos, M.L., Pereira, J.A., 2007. Antioxidant activity and phenolic contents of Olea europaea L. Leaves sprayed with different copper formulations. Food Chem. 103, 188-195.

Figueiredo-González, M., Valentão, P., Andrade, P.B., 2016. Tomato plant leaves: from by-products to the management of enzymes in chronic diseases. Ind. Crops Prod. 94, 621-629.

Figueiredo-González, M., Valentão, P., Pereira, D.M., Andrade, P.B., 2017. Further insights on tomato plant: cytotoxic and antioxidant activity of leaf extracts in human gastric cells Food Chem. Toxicol. 109, 386-392.

Fritsch, C., Staebler, A., Happel, A., Cubero Márquez, M., Aguiló-Aguayo, I., Abadias, M., Gallur, M., Cigognini, I., Montanari, A., López, M., Suárez-Estrella, F., Brunton, N., Luengo, E., Sisti, L., Ferri, M., Belotti, G., 2017. Processing, valorization and application of bio-waste derived compounds from potato, tomato, olive and cereals: a Review. Sustainability 9, 1492.

Galanakis, C.M., 2012. Recovery of high added-value components from food wastes: conventional, emerging technologies and 
commercialized applications. Trends Food Sci. Technol. 26, 68-87.

Galanakis, C.M., 2013. Emerging technologies for the production of nutraceuticals from agricultural by-products: a viewpoint of opportunities and challenges. Food Bioprod. Process. 91, 575-579.

Galanakis, C.M., 2015. Separation of functional macromolecules and micromolecules: from ultrafiltration to the border of nanofiltration. Trends Food Sci. Technol. 42, 44-63.

Galanakis, C.M., 2018. Phenols recovered from olive mill wastewater as additives in meat products. Trends Food Sci. Technol. 79, 98-105.

Galanakis, C.M., 2019. Dietary Fiber: Properties, Recovery, and Applications, 1st ed. Academic Press.

Galanakis, C.M., 2020. The food systems in the era of the coronavirus (COVID-19) pandemic crisis. Foods 9, 523.

Galanakis, C.M., Tsatalas, P., Galanakis, I.M., 2018. Implementation of phenols recovered from olive mill wastewater as UV booster in cosmetics. Ind. Crops Prod. 111, 30-37.

Gould, W.A., 1992. Tomato culture and production for processing. In: Tomato Production, Processing and Technology. Woodhead Publishing, pp. 19-81.

Gullón, B., Lú-Chau, T.A., Moreira, M.T., Lema, J.M., Eibes, G., 2017. Rutin: a review on extraction, identification and purification methods, biological activities and approaches to enhance its bioavailability. Trends Food Sci. Technol. 67, 220-235.

Gyawali, R., Ibrahim, S.A., 2014. Natural products as antimicrobial agents. Food Control 46, 412-429.

Hynstova, V., Sterbova, D., Klejdus, B., Hedbavny, J., Huska, D., Adam, V., 2018. Separation, identification and quantification of carotenoids and chlorophylls in dietary supplements containing Chlorella vulgaris and Spirulina platensis using High Performance Thin Layer Chromatography. J. Pharm. Biomed. Anal. 148, 108-118.

IBPGR, 1996. Descriptors for Tomato (Lycopersicon spp.). IBPGR Secretariat, Rome (Italy).

Independent Group of Scientists appointed by the Secretary-General, 2019. Global Sustainable Development Report 2019: The Future is Now - Science for Achieving Sustainable Development. United Nations, New York.

INE, 2019. Estatísticas Agrícolas - 2018. Instituto Nacional de Estatística, Lisboa.

Kim, S.E., Lee, M.Y., Lee, M.H., Sim, S.Y., Kim, Y.S., 2014. Optimal management of tomato leaf pruning in rockwool culture. Hortic. Environ. Biotechnol. 55, 445-454.

Kim, D.S., Kwack, Y., Lee, J.H., Chun, C., 2019. Antimicrobial activity of various parts of tomato plants varied with different solvent extracts. Plant Pathol. J. 35, 149-155.

Larbat, R., Paris, C., Le Bot, J., Adamowicz, S., 2014. Phenolic characterization and variability in leaves, stems and roots of Micro-Tom and patio tomatoes, in response to nitrogen limitation. Plant Sci. 224, 62-73.

Lockowandt, L., Pinela, J., Roriz, C.L., Pereira, C., Abreu, R.M.V., Calhelha, R.C., Alves, M.J., Barros, L., Bredol, M., Ferreira, I.C.F.R., 2019. Chemical features and bioactivities of cornflower (Centaurea cyanus L.) capitula: the blue flowers and the unexplored non-edible part. Ind. Crops Prod. 128, 496-503.

Mohamed, S.A., Awad, M.A., Al-Qurashi, A.D., 2014. Antioxidant activity, antioxidant compounds, antioxidant and hydrolytic enzymes activities of "Barhee" dates at harvest and during storage as affected by pre-harvest spray of some growth regulators. Sci. Hortic. 167, 91-99.

Mohamed, S.A., Awad, M.A., El-Dengawy, E.R.F.A., Abdel-Mageed, H.M., El-Badry, M.O., Salah, H.A., Abdel-Aty, A.M., Fahmy, A.S., 2016. Total phenolic and flavonoid contents and antioxidant activities of sixteen commercial date cultivars grown in Saudi Arabia. RSC Adv. 6, 44814-44819.

Nagata, M., Yamashita, I., 1992. Simple method for simultaneous determination of chlorophyll and carotenoids in tomato fruit. Nippon. Shokuhin Kogyo Gakkaishi 39, 925-928.
Naveed, M., Hejazi, V., Abbas, M., Kamboh, A.A., Khan, G.J., Shumzaid, M., Ahmad, F., Babazadeh, D., FangFang, X., Modarresi-Ghazani, F., WenHua, L., XiaoHui, Z., 2018. Chlorogenic acid (CGA): a pharmacological review and call for further research. Biomed. Pharmacother. 97, 67-74.

Noble, R., Elphinstone, J.G., Sansford, C.E., Budge, G.E., Henry, C.M., 2009. Management of plant health risks associated with processing of plant-based wastes: a review. Bioresour. Technol. 100, 3431-3446.

Pinela, J., Barros, L., Carvalho, A.M., Ferreira, I.C.F.R., 2012. Nutritional composition and antioxidant activity of four tomato (Lycopersicon esculentum L.) farmer' varieties in Northeastern Portugal homegardens. Food Chem. Toxicol. 50, 829-834.

Pinela, J., Oliveira, M.B.P.P., Ferreira, I.C.F.R., 2016. Bioactive compounds of tomatoes as health promoters. In: ds Silva, L.R., Silva, B.M. (Eds.), Natural Bioactive Compounds from Fruits and Vegetables as Health Promoters, Part II. Bentham Science Publishers, pp. 48-91.

Pinela, J., Barros, L., Barreira, J.C.M., Carvalho, A.M., Oliveira, M.B.P.P., Santos-Buelga, C., Ferreira, I.C.F.R., 2018. Postharvest changes in the phenolic profile of watercress induced by post-packaging irradiation and modified atmosphere packaging. Food Chem. 254, 70-77.

Pinela, J., Montoya, C., Carvalho, A.M., Martins, V., Rocha, F., Barata, A.M., Barros, L., Ferreira, I.C.F.R., 2019. Phenolic composition and antioxidant properties of ex-situ conserved tomato (Solanum lycopersicum L.) germplasm. Food Res. Int. 125, 108545.

Reis, F.S., Ferreira, I.C.F.R., Martins, A., 2011. Effect of the mycorrhizal symbiosis time in the antioxidant activity of fungi and Pinus pinaster roots, stems and leaves. Ind. Crops Prod. 35, 211-216.

Silva-Beltrán, N.P., Ruiz-Cruz, S., Cira-Chávez, L.A., Estrada-Alvarado, M.I., Ornelas-Paz, J., de, J., López-Mata, M.A., Del-Toro-Sánchez, C.L., Ayala-Zavala, J.F., Márquez-Ríos, E., 2015. Total phenolic, flavonoid, tomatine, and tomatidine contents and antioxidant and antimicrobial activities of extracts of tomato plant. Int. J. Anal. Chem. 2015, 2-4.

Soković, M., van Griensven, L.J.L.D., 2006. Antimicrobial activity of essential oils and their components against the three major pathogens of the cultivated button mushroom, Agaricus bisporus. Eur. J. Plant Pathol. 116, 211-224.

Soković, M., Glamočlija, J., Marin, P.D., Brkić, D., van Griensven, L.J.L.D., 2010. Antibacterial effects of the essential oils of commonly consumed medicinal herbs using an in vitro model. Molecules 15, 7532-7546.

Su, X., Griffin, J., Xu, J., Ouyang, P., Zhao, Z., Wang, W., 2019. Identification and quantification of anthocyanins in purple-fleshed sweet potato leaves. Heliyon 5, e01964.

Takebayashi, J., Iwahashi, N., Ishimi, Y., Tai, A., 2012. Development of a simple 96-well plate method for evaluation of antioxidant activity based on the oxidative haemolysis inhibition assay (OxHLIA). Food Chem. 134, 606-610.

Takwa, S., Caleja, C., Barreira, J.C.M., Soković, M., Achour, L., Barros, L., Ferreira, I.C.F.R., 2018. Arbutus unedo L. and Ocimum basilicum L. as sources of natural preservatives for food industry: a case study using loaf bread. LWT - Food Sci. Technol. 88, 47-55.

Taveira, M., Ferreres, F., Gil-Izquierdo, A., Oliveira, L., Valentão, P., Andrade, P.B., 2012. Fast determination of bioactive compounds from Lycopersicon esculentum Mill. Leaves. Food Chem. 135, 748-755.

Teitel, M., Liang, H., Levi, A., Harel, D., Alon, H., 2016. Effect of leaf pruning on energy partitioning and microclimate in an insect-proof screenhouse with a tomato crop. Biosyst. Eng. $151,1-8$.

Testai, L., 2015. Flavonoids and mitochondrial pharmacology: a new paradigm for cardioprotection. Life Sci., http://dx.doi.org/10.1016/j.lfs.2015.04.017.

Turumtay, E.A., Islamoğlu, F., Çavuş, D., Şahin, H., Turumtay, H., Vanholme, B., 2014. Correlation between phenolic compounds 
and antioxidant activity of Anzer tea (Thymus praecox Opiz subsp. Caucasicus var. caucasicus). Ind. Crops Prod. 52, 687-694. UPOV, 2013. TOMATO UPOV Code: SOLAN_LYC, Solanum lycopersicum L. Guidelines for the Conduct of Tests for Distinctness, Uniformity and Stability. TG/44/11 Rev.2. International Union for the Protection of New Varieties of Plants, Geneve.
Zinoviadou, K.G., Galanakis, C.M., Brnčić, M., Grimi, N., Boussetta, N., Mota, M.J., Saraiva, J.A., Patras, A., Tiwari, B., Barba, F.J., 2015. Fruit juice sonication: implications on food safety and physicochemical and nutritional properties. Food Res. Int. 77, 743-752. 